\title{
Complementary techniques to control cancer symptoms*
}

\author{
Técnicas complementares para controle de sintomas oncológicos
}

\author{
Aline Isabella Saraiva Costa ${ }^{1}$, Paula Elaine Diniz dos Reis ${ }^{2}$ \\ ${ }^{*}$ Received from the University of Brasilia, Brasilia, DF, Brazil.
}

\section{ABSTRACT}

BACKGROUND AND OBJECTIVES: Complementary techniques have positive impact on decreasing patients' stress and suffering, since their effects on the body decrease autonomic nervous system activity, responsible for the control of visceral and homeostatic functions essential to life. This study aimed at identifying evidences in the scientific literature with regard to the use of complementary techniques to control cancer patients' signs and symptoms.

CONTENTS: Literature was reviewed as from LILACS, CINAHL, Cochrane and Medline databases using the descriptors terapia de relaxamento and dor and cancer, Relaxation Therapy and Pain and Cancer, in the period from 2002 to 2013. Eight randomized controlled clinical trials investigating the effects of complementary techniques to control anxiety, pain, fatigue and sleep in oncology were identified. Complementary techniques were beneficial to decrease pain intensity, to improve pain control perception and pain-related fatigue, to decrease anxiety and to improve sleep quality, thus leading to physical improvement. CONCLUSION: Studies have shown the effectiveness of the technique which, when adequately used, decreases perception of pain, fatigue, sleep, dyspnea and anxiety, thus helping to improve quality of life.

Keywords: Complementary therapies, Neoplasia, Pain, Signs and symptoms.

\section{RESUMO}

JUSTIFICATIVA E OBJETIVOS: As técnicas complementares apresentam impacto positivo na redução do estresse e sofrimento

1. University of Brasília, Nursing Department, Brasília, DF, Brazil.

2. University of Brasília, School of Health Sciences, Nursing Department, Brasília, DF, Brazil.

Submitted in July 08, 2013.

Accepted for publication in January 21, 2014.

Conflict of interests: none.

Correspondence to:

Aline Isabella Saraiva Costa

SQN 404, Bloco H, apt ${ }^{\circ} 202$ - Asa Norte

70845-080 Brasília, DF, Brasil.

E-mail: aline.sa.costa@hotmail.com

( ) Sociedade Brasileira para o Estudo da Dor do paciente, visto que seus efeitos no organismo reduzem a atividade do sistema nervoso autônomo, responsável pelo controle das funçôes viscerais e homeostáticas essenciais à vida. $\mathrm{O}$ objetivo deste estudo foi identificar evidências na literatura científica relacionadas ao uso de técnicas complementares para o controle de sinais e sintomas em pacientes com câncer.

CONTEÚDO: A revisão de literatura foi realizada a partir das bases de dados LILACS, CINAHL, Cochrane e Medline, usando os descritores terapia de relaxamento and dor and câncer, Relaxation Therapy and Pain and Cancer no período de 2002 a 2013. Identificou-se 8 ensaios clínicos controlados e aleatórios que investigaram o efeitos das técnicas complementares no controle de ansiedade, dor, fadiga, sono, na oncologia. As técnicas complementares mostraram-se benéficas na redução da intensidade da dor, percepção de controle sobre a dor, angústia relacionada à dor, fadiga, reduçáo da ansiedade, aumento da qualidade do sono e consequente melhora física.

CONCLUSÁO: Os estudos demonstraram a eficácia da técnica que, quando bem empregada, obtém diminuição da percepção da dor, fadiga, sono, dispneia e ansiedade, corroborando assim para uma melhora na qualidade de vida. A técnica de relaxamento apresenta como vantagens o baixo custo, dispensa de recursos tecnológicos, além da facilidade de ser aplicável por qualquer profissional da área de saúde, desde que esteja habilitado.

Descritores: Dor, Neoplasias, Sinais e sintomas, Terapias complementares.

\section{INTRODUCTION}

Complementary therapies are gaining space among therapeutic options in North-American cancer treatment centers. Among the reasons for such acceptance is the immediate positive impact on patients stress and distress, the relative easiness of their application and the provided feeling of control. Several cognitive-behavioral procedures have been used in cancer treatment, more specifically to minimize severe treatment-induced adverse effects, such as: cognitive/attention distraction, hypnosis/guided imagery systematic desensitization, cognitive restructuring and relaxation trainings ${ }^{1}$.

Relaxation therapy is an accessible technique which helps the attainment of body/mind balance. Its effects on the body may be easily understood if one considers that there is decreased autonomous nervous system activity, responsible for visceral and homeostatic functions essential to life ${ }^{1}$. It has as benefits the improvement of feelings such as distress, pain, tensions, anxiety, heart rate and blood pressure, in addition to promoting energy and sleep. 
The Federal Council of Nursing Resolution (COFEN-197/97) establishes and recognizes Complementary Therapies as specialty or qualification of Nursing professionals, provided professionals have finished and being approved by a recognized course by teaching institution or similar entity, with minimum workload of 360 hours $^{2}$. Some simpler complementary practices are used as non-pharmacological treatment and are performed during nursing consultations and taught to patients, thus contributing to cancer patients' pain control. Based on this assumption, this study aimed at identifying evidences in the scientific literature on the use of complementary techniques to control signs and symptoms of cancer patients.

\section{CONTENTS}

This is a literature review as from the search of articles in LILACS, CINAHL, Cochrane and Medline databases, using as keywords for the LILACS database: terapia de relaxamento and dor and câncer, and for Medline, CINAHL and Cochrane databases the keywords: relaxation therapy and pain and cancer. Search ended up with 266 articles, however after randomized studies selection criteria, with complementary techniques available in Portuguese, English and Spanish, published between 2003 and 2013, eight studies have remained for evaluation. Articles were characterized by used tools, socioeconomic and clinical characteristics and outcome (Table 1).

Table 1. Characteristics of clinical trials findings

\begin{tabular}{|c|c|c|c|}
\hline Authors & Used tools /Sample & $\begin{array}{l}\text { Sociodemographic charac- } \\
\text { teristics }\end{array}$ & Clinical characteristics \\
\hline $\begin{array}{l}\text { McChargue } \\
\text { et al. }{ }^{3}\end{array}$ & $\begin{array}{l}\text { HADS, SES \& Karnofsky. } \\
113 \text { people. Random- } \\
\text { ized. }\end{array}$ & $\begin{array}{l}97 \% \text { were Caucasian; } 63 \% \\
\text { earned more than } 40.000 \\
\text { U\$; } 42.5 \% \text { high school or } \\
\text { college; } 69.9 \% \text { were mar- } \\
\text { ried. }\end{array}$ & $\begin{array}{l}50.4 \% \text { of females were in meno- } \\
\text { pause and above weight, Stag- } \\
\text { ing: } \\
\text { I }(29 \%) \text {, II }(57 \%) \text {, III }(14 \%) \text {. }\end{array}$ \\
\hline $\begin{array}{l}\text { Kwekkeboom } \\
\text { et al. }{ }^{4}\end{array}$ & $\begin{array}{l}\text { VAS, BPI, BFI, PSQI, ASI } \\
\text { \& Profile of Mood States } \\
\text { - short form. } \\
78 \text { participants. }\end{array}$ & $\begin{array}{l}67 \% \text { females, } 100 \% \text { were } \\
\text { not Latin or Hispanic; } 96 \% \\
\text { Caucasian; } 60 \% \text { college. }\end{array}$ & $\begin{array}{l}49 \% \text { with gynecological cancer; } \\
70 \% \text { chemotherapy, } \\
98 \% \text { dizziness, } 77 \% \text { oblivion, } \\
72 \% \text { dry mouth; } 58 \% \text { opioids, } \\
74 \% \text { steroids, } 86 \% \text { antiemetics. }\end{array}$ \\
\hline Lee et al. ${ }^{5}$ & $\begin{array}{l}\text { SAI, perception of relax- } \\
\text { ation treatment. Electro- } \\
\text { encephalogram. } \\
43 \text { patients. Randomi- } \\
\text { zed. }\end{array}$ & $\begin{array}{l}\text { Age between } 27 \text { and } 65 \\
\text { years, mean control group } \\
\text { age (MC) } 49.3 \text { years and } \\
\text { intervention (PMR) } 51.3 \\
\text { years. }\end{array}$ & $\begin{array}{l}\text { Fortecortin }(\mathrm{MC}=21, \mathrm{PMR}=20) \text {, } \\
39 \\
\text { Granisetron }(\mathrm{MC}=21, \mathrm{PMR}=18) \text {, } \\
\text { Aprepitant }(\mathrm{MC}=16, \mathrm{PMR}=14) .\end{array}$ \\
\hline $\begin{array}{l}\text { Demiralp, } \\
\text { Oflaz, } \\
\text { Komurcu }^{6}\end{array}$ & $\begin{array}{l}\text { PSQI, The Piper Fatigue } \\
\text { Scale. } \\
27 \text { individuals. }\end{array}$ & $\begin{array}{l}\text { No demographic data of } \\
\text { the study. }\end{array}$ & No clinical data of the study \\
\hline Haase et al. ${ }^{7}$ & $\begin{array}{l}\text { VAS } \\
74 \text { randomized patients. }\end{array}$ & $\begin{array}{l}\text { Age } 54-76 \text { years, } 62 \% \text { were } \\
\text { females. }\end{array}$ & $\begin{array}{l}\text { Staging: I (35\%), II }(26 \%) \text {, III } \\
(30 \%) \text {. } \\
68 \% \text { had stomas. }\end{array}$ \\
\hline
\end{tabular}

Outcome

Adhesion to relaxation technique (58-70\%). Sleep disorders, pain and anxiety significantly decreased.

Behavioral therapy was used in average 13.65 times. There has been improvement of pain, fatigue and sleep in the intervention group.

Both MC and PMR groups have shown significant improvement in physical health and psychological status, such as anxiety. Listening to recorded $\mathrm{MC}$ sounds and practice PMR is useful for gynecological cancer patients during chemotherapy.

PMR intervention group had improved sleep quality and fatigue.

$79 \%$ admitted the benefits of interventions. However both guided image and relaxation had positive responses but without clinical relevance.

Singh et al. ${ }^{8} \quad$ VASD, STAI, measurement of vital signs. 82 randomized patients.

Kwekkeboom, Imaging Ability QuestionWanta \& naire, Wisconsin ExperiBumpus $^{9} \quad$ ence Questionnaire, The Outcome Expectancy Scale, The Edmonton Symptom Assessment System.

40 patients

Kwekkeboom NRS, Perception of theret al. ${ }^{10}$ apy used. 26 patients. Randomized.
Mean age 63 years, $70 \%$ No details, just class of drugs of males in intervention used. groups.

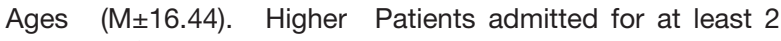
number of males has not days with pain equal to or above completed the study (34\%). 2 in the last 24 hours.
Music is more effective for dyspnea and anxiety because it is easier to apply.

Images, PMR and analgesics may be beneficial to treat acute or episodic pain in some patients.
Age 18 to 72 years $(M=43,77 \%$ had malignant hematologic $\mathrm{SD}=16) ; 16$ were females, disease; 69\% received chemo$62 \%$ Caucasian; $85 \%$ ed- therapy or radiotherapy; somatic ucation level above high pain (69\%); school.
There have been changes in pain scores: effective intervention influenced by active development during intervention.
$69 \%$ used morphine, hydromorphine, fentanyl or methadone. 


\section{DISCUSSION}

Increased people survival justifies the search for non-pharmacological methods providing better quality of life for cancer patients. Studies involve behavioral techniques aiming at relieving symptoms, among them sleep, fatigue, dyspnea and anxiety. Some characteristics of each study are described below.

In a clinical trial ${ }^{3}$ aiming at establishing adherence rates to a sleep behavioral therapy and at identifying psychological and physical symptoms in females submitted to chemotherapy for breast cancer, authors have used as intervention: stimulations control, modified sleep restriction, relaxation therapy and sleep hygiene concepts. Several measurement tools were used, which allowed to observe that total adherence rate to the behavioral therapy plan was $51-52 \%$ in all four treatment modalities. Sleep disorders, pain and anxiety have significantly improved with the use of techniques during chemotherapy; 58 to $70 \%$ of patients have shown more adherence to the relaxation technique. However the number of participants has decreased throughout the research, which may have caused bias.

In a double clinical trial ${ }^{4}$ aiming at evaluating the initial efficacy of cognitive-behavioral intervention (CB) for pain, fatigue and sleep, authors have published information about: 1) causes of pain, fatigue and sleep disorders during cancer treatment, 2) expected behavioral effects on symptoms, 3) overview of 12 behavioral therapy strategies used by the study, and 4) individual recommendations about the practice of $\mathrm{CB}$ intervention. It was observed that there has been significant difference in decreasing pain and fatigue in the intervention group. Authors have suggested that cognitive-behavioral therapy might not be as effective for sleep disorders as it is for pain and fatigue. However, there has been difference in sleep disorders decrease in the experimental group as compared to control group.

Another strategy was the use of monochord sounds $(\mathrm{MC})^{5}$, where authors have investigated, as from both subjective and neurobiological perspectives, the extension of MC therapeutic effects on breast or gynecological cancer patients submitted to chemotherapy and have compared such effects with those obtained with progressive muscle relaxation (PMR).

Patients of both groups had significant physical and mental health improvement. EEG data have shown that MC and PMR groups were associated to posterior theta $(3.5-7.5 \mathrm{~Hz})$ increase and midfrontal beta-2 band of activity decrease $(20-29.5 \mathrm{~Hz})$ during the final stage of the relaxation treatment. In addition, MC group was associated to decreased alpha band $(8-12 \mathrm{~Hz})$ activity as compared to the PMR group. This study has shown that both listening to recorded MC sounds and practicing PMR had positive relaxing effects, decreasing anxiety and promoting well-being. Authors have encouraged other investigators to continue studying monochord sounds applied to oncology aiming at improving patients both physically and psychologically, not only in the clinical context but also in home care.

Another study ${ }^{6}$ evaluating sleep has used PMR to promote sleep quality and fatigue levels improvement in breast cancer patients. Data were collected in four moments and each session lasted approximately 25-30 minutes. Results have shown that PMR training has improved sleep and fatigue quality in breast cancer patients under adjuvant chemotherapy. Authors have identified a possible selection bias due to the small sample size. In addition, they have stressed the importance of starting relaxation training before chemotherapy to decrease frequency and severity of sleep and fatigue problems during chemotherapy.

Another technique has used guided imagery ${ }^{7}$, where authors have used tapes with instructions for its execution, aiming at investigating possible differences between guided imagery and PMR in elderly patients in the postoperative period of colon cancer. Patients would receive a tape with 12 minutes of instructions for guided imagery or PMR, being such tapes developed and recorded by an expert. No tape had religious or spiritual references. Patients were randomized in three groups: guided imagery, PMR and control. The guided imagery tape asked patients to stay calm and look for their inner self. Patients were induced to an imaginary trip to a special place where they could feel themselves safe, comfortable and supported, being encouraged to cope and work with anxiety and stress feelings. The PMR tape oriented patients to imagine muscle contraction and relaxation. To increase this sensation, patients were oriented to breathe and feel heat and weight wherever they wished. All tapes had the same soundtrack and had no hypnotic messages, according to authors. The outcome of the study was that both guided imagery and relaxation had positive responses, but had no clinical relevance for the postoperative physiological course of elderly patients submitted to conventional colorectal cancer resection.

Also using the PMR technique, a clinical trial ${ }^{8}$ has compared its efficacy with music therapy in patients with chronic obstructive lung disease after acute episodes. Patients could choose the soundtrack and would listen with earphones. Participants were oriented to sit comfortably and concentrate on the song with closed eyes during 30 minutes, twice a day (morning and afternoon). In the PMR technique, patients would sit in equally comfortable chairs and would listen to instructions from a recorded tape about muscle relaxation technique according to the procedure recommended by Bernstein and Borkovec to release tension in 16 major muscle groups. One hypothesis was that music is easy to apply, that is, it would be only necessary to listen, differently from relaxation technique where one has to listen and follow tape instructions.

In a different study, the same authors ${ }^{9}$ aimed at evaluating variation of results achieved with PMR and guided imagery among admitted patients with cancer pain, in addition to evaluating the influence of four individual variables (cognitive capacity, expectation of result, previous experience and simultaneous symptoms) in pain relief obtained with each intervention. When comparing means of treatment and control conditions, both PMR and imagery have produced major improvements in pain intensity, pain-related distress and perception of pain control. However, the individual response analysis has shown that only half the patients have obtained significant pain improvement with the intervention. Patients with significant pain improvement with imagery have reported better imagination skills. Authors have emphasized the need for further studies to identify factors which moderate the effects of cognitive-behavioral therapy with regard 
to pain and how to handle strategies so that clinicians are able to identify most beneficial approaches to patients.

In addition to the proper use of complementary techniques, there is the need to engage people using them aiming at validating whether the technique will reach expected results. So, authors ${ }^{10}$ have compared patients' perception, asking them about the factor which could influence the efficacy of guided imagery and PMR interventions. Interviews have shown that participants' perception about treatment effects have changed pain scores. From all respondents, $81 \%$ have reported that PMR intervention relieved pain. In general, the perception of PMR efficacy has changed pain in 14 cases $(54 \%)$ and 16 participants (62\%) have referred that guided imagery has relieved pain, what was confirmed by decreased pain scores. Most participants have reported that if both cognitive-behavioral techniques should have lasted longer, it would have been more beneficial.

This review shows the beneficial effects of complementary therapies, but there is the need for further controlled and randomized clinical trials about controlling signs and symptoms in oncology. Advanced cancer symptoms are a subject instigating many professionals, what encourages the search for new answers for evaluation and control. So, health professionals should play their role in controlling pain, sleep, fatigue and anxiety to evaluate, intervene and monitor. Taking into consideration this set of factors which interact with chronic cancer pain is an important step in cancer patients' care $^{11}$.

\section{CONCLUSION}

Scientific evidences point to the benefits of non-pharmacological approaches to control cancer signs and symptoms. Behavioral therapy was effective to decrease pain intensity, pain perception and control, pain-related distress, fatigue, decrease anxiety, increase sleep quality and consequent physical improvement. Professionals may use such techniques in their daily activities at the office, hospitals and home care. In addition, its advantages are low cost, unnecessary use of technological resources and the easiness of being applicable by any qualified health professional.

\section{REFERENCES}

1. Lopes RF, Santos MR, Lopes EJ. Efeitos do relaxamento sobre a ansiedade e desesperança em mulheres com câncer. Rev Bras Ter Comp Cogn. 2008;10(1):39-49.

2. Brasil. Resoluçăo COFEN - 197/1997. Estabelece e reconhece as Terapias Alternativas como especializaçáo e/ou qualificaçăo do profissional de Enfermagem. Disponível em: http://www.abenanacional.com.br/Resolucao\%20COFEN\%20197\%201997.pdf. Acesso 17 abril 2013.

3. McChargue DE, Sankaranarayanan J, Visovsky CG, Matthews EE, Highland $\mathrm{KB}$, Berger AM. Predictors of adherence to a behavioral therapy sleep intervention during breast cancer chemotherapy. Support Care Cancer, 2012;20(2):245-52.

4. Kwekkeboom KL, Abbott-Anderson K, Cherwin C, Roiland R, Serlin RC, Ward SE Pilot randomized controlled trial of a patient-controlled cognitive-behavioral intervention for the pain, fatigue, and sleep disturbance symptom cluster in cancer. J Pain Symptom Manage, 2012;44(6):810-22

5. Lee EJ, Bhattacharyab J, Sohn C, Verres R. Monochord sounds and progressive muscle relaxation reduce anxiety and improve relaxation during chemotherapy: a pilot EEG study. Complement Ther Med. 2012;20(6):409-16.

6. Demiralp M, Oflaz F, Komurcu S. Effects of relaxation training on sleep quality and fatigue in patients with breast cancer undergoing adjuvant chemotherapy. J Clin Nurs. 2010; 19(7-8):1073-83.

7. Haase O, Schwenk W, Hermann C, Müller JM. Guided imagery and relaxation in conventional colorrectal resections: a randomized, controlled, partially blinded trial. Dis Colon Rectum. 2005;48(10):1955-63.

8. Singh VP, Rao V, Prem V, Sahoo RC, Keshav Pai K. Comparison of the effectiveness of music and progressive muscle relaxation for anxiety in COPD--A randomized controlled pilot study. Chron Respir Dis. 2009;6(4);209-16.

9. Kwekkeboom KL, Wanta B, Bumpus M. Individual difference variables and the effects of progressive muscle relaxation and analgesic imagery interventions on cancer pain. J Pain Symptom Manage. 2008;36(6):604-15.

10. Kwekkeboom KL, Hau H, Wanta B, Bumpus M. Patients' perceptions of the effectiveness of guided imagery and progressive muscle relaxation interventions used for cancer pain. Complement Ther Clin Pract. 2008;14(3):185-94.

11. Costa AI, Chaves MD. Dor em pacientes oncológicos sob tratamento quimioterápico. Rev Dor. 2012;12(1):45-9. 